\title{
Use of mobile and cordless phones and change in cognitive function: a prospective cohort analysis of Australian primary school children
}

Chhavi Raj Bhatt ${ }^{1}$, Geza Benke ${ }^{1}$, Catherine L. Smith ${ }^{1}$, Mary Redmayne ${ }^{1}$, Christina Dimitriadis ${ }^{1}$, Anna Dalecki ${ }^{2}$, Skye Macleod ${ }^{2}$, Malcolm R. Sim ${ }^{1}$, Rodney J. Croft ${ }^{1,2}$, Rory Wolfe ${ }^{1}$, Jordy Kaufman ${ }^{3}$ and Michael J. Abramson ${ }^{1 *}$

\begin{abstract}
Background: Some previous studies have suggested an association between children's use of mobile phones (MPs)/cordless phones (CPs) and development of cognitive function. We evaluated possible longitudinal associations between the use of MPs and CPs in a cohort of primary school children and effects on their cognitive function.

Methods: Data on children's socio-demographics, use of MPs and CPs, and cognitive function were collected at baseline (2010-2012) and follow-up (2012-2013). Cognitive outcomes were evaluated with the CogHealth ${ }^{\mathrm{TM}}$ test battery and Stroop Color-Word test. The change in the number of MP/CP voice calls weekly from baseline to follow-up was dichotomized: "an increase in calls" or a "decrease/no change in calls". Multiple linear regression analyses, adjusting for confounders and clustering by school, were performed to evaluate the associations between the change in cognitive outcomes and change in MP and CP exposures.

Results: Of 412 children, a larger proportion of them used a CP (76\% at baseline and follow-up), compared to a MP (31\% at baseline and $43 \%$ at follow-up). Of 26 comparisons of changes in cognitive outcomes, four demonstrated significant associations. The increase in MP usage was associated with larger reduction in response time for response inhibition, smaller reduction in the number of total errors for spatial problem solving and larger increase in response time for a Stroop interference task. Except for the smaller reduction in detection task accuracy, the increase in CP usage had no effect on the changes in cognitive outcomes.

Conclusion: Our study shows that a larger proportion of children used CPs compared to MPs. We found limited evidence that change in the use of MPs or CPs in primary school children was associated with change in cognitive function.
\end{abstract}

Keywords: Cognitive function, Cordless phone use, Mobile phone use, Primary school children

\section{Background}

The use of mobile phones (MPs) and cordless phones (CPs) by young children has become common worldwide [1-6]. This has raised concerns regarding the potential health and psychological effects of MPs and CPs on the developing brains of children [7-11]. The

\footnotetext{
* Correspondence: michael.abramson@monash.edu

${ }^{1}$ Centre for Population Health Research on Electromagnetic Energy (PRESEE), School of Public Health and Preventive Medicine, Monash University, $553 \mathrm{St}$ Kilda Road, VIC 3004 Melbourne, Australia

Full list of author information is available at the end of the article
}

World Health Organization (WHO) has identified research into children's behavioral and neurological outcomes associated with radio-frequency electromagnetic field (RF-EMF) exposure as a high priority RF-EMF agenda [8].

The use of MPs or/and CPs in children has been associated with negative consequences in cognitive functioning $[1,12]$, including memory performance [11] and emotional and behavior difficulties [13]. However, there are few community-based epidemiological studies involving children that assessed effects of MP 
and/or CP use on cognitive functioning [1, 10-12, 14]. The findings of these studies are inconclusive $[1,11,12$, 14]. A recent Swiss study involving adolescents found a negative association between MP and CP use with figural memory [11]. The Amsterdam Born Children and their Development $(A B C D)$ study showed inconsistent associations between MP and $\mathrm{CP}$ use and cognitive function [14]. Furthermore, our cross-sectional analysis of the ExPOSURE (Examination of Psychological Outcomes in Students Using Radiofrequency dEvices) study found little evidence for an association between the use of MPs and CPs and cognitive effects in a cohort of primary school children in Australia [10].

The aim of this prospective analysis of the ExPOSURE study data was to evaluate possible longitudinal associations between the use of MPs and CPs in a cohort of primary school children and effects on their cognitive function.

\section{Methods}

\section{Study design and participants}

A longitudinal study was undertaken among primary school children (the $4^{\text {th }}$ year) in Melbourne and Wollongong, Australia. Baseline $(n=619)$ and followup $(n=412)$ data were collected from 36 schools during November 2010-February 2012 and March 2012March 2013, respectively. In Melbourne, schools were stratified as public (state), Catholic and private schools for recruitment. The schools located in central Melbourne regions and various adjoining regions were selected to be invited based on systematic sampling in each group of school type. Since the target number of schools was not recruited from central Melbourne and adjoining regions, schools outside of the originally selected regions were also invited to participate. The schools that agreed to participate were included in the study. The contact person from the schools nominated a class or classes to participate in the study. In Wollongong, all public and Catholic schools located within the greater Illawarra area were invited. Of them, all the schools that agreed to participate were included in the study. The schools that agree to participate then selected one or more grade four class(s) to be invited to take part in the study. Further details about sampling can be found elsewhere [10].

Written or verbal informed consent was obtained from the parent/guardian of each student, teachers of the participating classes, and principals of the participating schools. The study also received approvals from the Victorian Department of Education and Early Childhood Development, New South Wales Department of Education and Communities, Catholic Education Offices of Victoria and New South Wales, Monash University Human Research Ethics Committee and the University of Wollongong Human Research Ethics Committee.
The information on socio-demographics and that related to MP or/and CP use or ownership were collected at baseline and follow-up. Cognitive outcomes were also assessed at the two time points.

\section{Exposure assessment}

The parents/guardians of participating children completed a modified and validated questionnaire from the Interphone study [15], which collected information on their children's MP and $\mathrm{CP}$ use, such as average number of MP calls (made and received) weekly, duration of each (outgoing and incoming) MP call weekly, average number of text messages or SMS (sent and received) weekly, average number of $\mathrm{CP}$ calls (made and received) weekly, and duration of each call on $\mathrm{CP}$ weekly. In addition, we also gathered socio-demographic information such as age, sex, country of birth, ethnicity (languages other than English spoken at home) and residential post code. The parents were also asked about their perception of their and their family's health risk in relation to MP use. The children, assisted by research staff, completed a questionnaire about whether or not they owned or used a MP, laterality of MP use, handedness (right or left handed), and the amount of gaming and computer/Internet use.

\section{Outcome assessment}

Cognitive outcomes were assessed with a computerized CogHealth $^{\text {Tm }}$ test battery (CogState, Melbourne, AU, 2005) $[1,10,12]$, and the Stroop Color-Word test [16].

CogHealth $^{\text {tw }}$ evaluated signal detection (simple reaction), identification (choice reaction), one-back (working memory), one card learning (visual attention), Go/No-Go (response inhibition), and Groton maze learning (spatial and executive ability) [10]. Further details of testing administration are discussed elsewhere $[10,12]$. The total number of errors for the spatial problem solving function, and response times (ms) and accuracy (\%) for the rest of the $\mathrm{CogHealth}^{\text {Tix }}$ cognitive tests were assessed.

The Stroop Color-Word test: This test assessed the ability to name colors and words that are presented in conjunction with interfering stimulus characteristics (e.g., naming the written word 'red', presented in blue hue) [17]. The task has four sub-tests, two to provide baseline information (no interference), and two interference conditions $[1,12]$. These tests measured response time for each form and time ratios were subsequently estimated. Further details of the test can be found in the literature $[1,16]$.

\section{Statistical analyses}

Descriptive analyses were performed for socio-demographics and MP and CP use. The descriptive analyses for exposure measures, CogHealth ${ }^{\text {Ta }}$ tasks, Stroop Color-Word test, and 
regression analyses were performed for the students taking part both in baseline and follow-up $(n=412)$. Socioeconomic status (SES) was estimated from socio-economic indexes for areas in accordance with children's residential postal codes [18].

RF-EMF exposure measures were the total number of voice calls (made and received) weekly for $\mathrm{MP}$ and $\mathrm{CP}$ separately. We used reported numbers of MP and $\mathrm{CP}$ calls as the proxies for MP and CP exposures, respectively $[1,10,12]$, because they may be more accurate in ascertaining the phone use compared to the duration of calls' $[19,20]$. We did not consider SMS use as an exposure, firstly because RF-EMF exposure to the head due to SMS would be very low, and secondly because SMS use was very low in this age group. MP use was low in both surveys. For the MP/CP users, the numbers of reported voice calls weekly on MPs and CPs were low (i.e., median at baseline $=2$ ), with no use of MP/CP represented as zero calls. Therefore, the exposure metrics at baseline and follow-up were further classified in terms of the three groups: no use ('none'), $\leq 2$ voice calls weekly on $\mathrm{MP} / \mathrm{CP}$ ('some'), and $>2$ voice calls weekly on MP/CP ('more'). Cognitive parameters were summarized across these three groups. The mean response time of each test was $\log _{10}$ transformed and the square root of each accuracy score was arcsine transformed [1, 12]. The Stroop Color-Word test data were analyzed by comparing the time ratios of response times (in seconds) of form $B$ and form $A$ [i.e., (B-A)/A], and those of form $D$ and form $C$ [i.e., $(D-C) / C]$.

Multiple linear regression models with robust standard errors, allowing for clustering of students within schools, were used to assess the association between the change in cognitive outcome (follow-up minus baseline) in children who increased their MP (or CP) weekly calls from baseline to follow-up, and those who did not increase their MP (or CP) usage. The models were adjusted for age at baseline, sex, ethnicity, SES (classified into quintiles), lag time between baseline and follow-up, handedness and total screen time weekly (i.e., gaming and computer/Internet use).

Changes in MP and CP voice calls weekly from baseline to follow up were dichotomized as follows: $0=$ decrease or no change in number of MP and $\mathrm{CP}$ voice calls weekly, or $1=$ increase in number of $\mathrm{MP}$ and $\mathrm{CP}$ voice calls weekly. The models also considered the potential interaction between gender and MP and $\mathrm{CP}$ use in an exploratory analysis. Seven children with attention deficit hyperactivity disorder were excluded from the regression analysis. For all analyses, $p \leq 0.05$ (twosided) was considered as statistically significant. Data analysis was performed with STATA ver13.1 (StataCorp, College Station, TX, USA) or SPSS (version 22, IBM Corp, Armonk, NY, USA).

\section{Results}

\section{Descriptive data}

Table 1 shows socio-demographic characteristics, and MP and CP use of the children taking part in baseline and follow-up. Of 619 baseline participants, 412 (66.5\%) took part in the follow-up study. The mean $( \pm$ SD) time lag between the baseline and follow-up studies was 12.4 \pm 2 months. Most of the participants at baseline and follow-up were from high socio-economic areas. Ethnicity (language other than English spoken at home) and country of birth (Australia) of children was similar at baseline and follow-up. The handedness also remained largely unchanged from baseline and follow-up - right (87\%), left (10.3\%), no preference $(2.2 \%)$ [baseline], and right $(86 \%)$, left $(10 \%)$ and no preference $(\sim 4 \%)$ [follow-up]

According to the parental responses, nearly $31 \%$ of children at baseline and $43 \%$ at follow-up owned or used a MP. In contrast, $57 \%$ of children at baseline and $68 \%$ at follow-up reported having owned or used a MP. The use of a CP at home was reported for $76 \%$ of the children both at baseline and follow-up.

Table 2 shows MP and CP calls, MP SMS, and MP and CP use for the children who took part both in baseline and follow-up. Overall, weekly MP voice calls and SMS significantly increased ( $p<0.001$ for both), whereas weekly $\mathrm{CP}$ voice calls remained unchanged $(p=0.26)$, from baseline to follow-up. For the MP/CP users, the median numbers of voice calls (made and received) weekly for MP and CP were 2 and 2 at baseline, and 2.5 and 2 at follow-up, respectively.

Of the parents taking part in both waves of surveys, $33.6 \%$ at baseline and $31 \%$ at follow-up considered that MPs posed low risk to them and their family's health. Likewise, $21 \%$ at baseline and $22 \%$ at follow-up considered that MPs posed moderate risk. However 37\% at baseline and follow-up did not know if MP use posed a health risk. Only a few parents (nearly 5\% at baseline and follow-up) considered MPs to represent a high health risk. Five percent at baseline and follow-up also considered MP use to pose no health risk.

There were no significant differences between those who continued to participate $(n=412)$ and drop outs $(n=207)$ in age, sex, ethnicity, ownership or use of MP, laterality of MP use, handedness, total average number of calls (made and received) weekly on MPs, total average number of calls (made and received) weekly on CPs, total average number of SMS messages (sent and received) weekly on MPs. Nor were there differences in their baseline response times for the detection task, visual recognition and attention, and working memory; response time and accuracy for the identification task, or response inhibition task. 
Table 1 Socio-demographic, mobile and cordless phone use characteristics of children

\begin{tabular}{lll}
\hline Variables & Baseline $[n=619]$ & Follow-up [n=412] \\
Age (mean \pm SD) & $10 \pm 0.4$ years & $11 \pm 0.5$ years \\
Sex & $53 \%(n=329)$ girls & $55 \%(n=227)$ girls \\
Ownership/use of a MP (parent's response) & $31.0 \%(n=187)$ & $43.3 \%(n=168)$ \\
Ownership/and use of a MP (children's response) & $57.3 \%(n=353)$ & $67.9 \%(n=279)$ \\
Laterality of MP use & Right: $68.2 \%(n=262)$ & Right: $74.2 \%(n=250)$ \\
& Left: $11.5 \%(n=44)$ & Both: $14.0 \%(n=47)$ \\
Use of a CP at home & Both: $18.5 \%(n=71)$ & $76.2 \%(n=314)$ \\
Average duration per call (minutes) weekly & $76 \%(n=470)$ & Median $\left(25^{\text {th }}, 75^{\text {th }}\right.$ percentiles $)$ \\
A call dialed on MP & Median $\left(25^{\text {th }}, 75^{\text {th }}\right.$ percentiles $)$ & $2(1,3)$ \\
A call received on MP & $2(1,3)$ & $1.5(0.5,3)$ \\
Call (dialed $\&$ received) on CP & $1.5(0,3)$ & $4(2,5.5)$ \\
\hline
\end{tabular}

Compared to the children who were followed-up, the drop-outs were more likely to be in the lower two quintiles of SES, rather than the higher three quintiles of SES. The drop-outs also owned and used MPs and CPs less, had higher Stroop time ratios, response inhibition task, less accuracy in the Groton maze and detection tasks, visual recognition and attention and working memory (data not shown).

Tables 3, 4 and 5 summarize cognitive outcome data of the children who used MP and CP and took part in both waves of surveys. Table 3 compares data of CogHealth $^{\text {та }}$ cognitive outcomes (untransformed) in those children who used MPs. Table 4 compares the data of the cognitive outcomes in those children who used CPs. Table 5 summarizes the cognitive outcome data of the Stroop Color-Word tests. These data show that response times tended to be faster and accuracy similar or better at follow-up compared to baseline in most cases.

\section{Association between change in cognitive function, and change in the use of mobile and cordless phones}

Table 6 compares the change in cognitive outcome (follow-up minus baseline) between those who increased their MP/CP weekly calls from baseline to follow-up, and those who did not increase or reduce their MP/CP usage.

Compared to the 'no change or decrease' group, the 'increase' in total average number of MP calls weekly group had significantly: i) larger mean reduction in response time for the Go/NoGo task, ii) smaller mean reduction in the number of total errors in executing the Groton maze learning task, and iii) larger mean increase in response time for the Stroop time ratio ((B-A)/A).

Table 2 MP and CP exposure measures [baseline \& follow-up participants $(n=412)$ ]

\begin{tabular}{|c|c|c|c|}
\hline Total number of MP and CP calls/SMS weekly ${ }^{\mathrm{a}}$ & Baseline & Follow-up & \\
\hline & \multicolumn{2}{|c|}{ Median $\left(25^{\text {th }}, 75^{\text {th }}\right.$ percentiles $)$} & ${ }^{b_{p} \text {-value }}$ \\
\hline MP voice calls (dialed \& received) & $2(1,5)$ & $2.5(1,5.2)$ & $<0.001$ \\
\hline MP SMS (sent \& received) & $0.5(0,4)$ & $2(0,7.5)$ & $<0.001$ \\
\hline CP voice calls (dialed \& received) & $2(1,4)$ & $2(1,4)$ & 0.26 \\
\hline MP and CP usage ${ }^{c}$ & \multicolumn{3}{|c|}{ Proportion (number) of children } \\
\hline \multicolumn{4}{|l|}{ MP voice calls } \\
\hline No use & $69.7 \%(n=279)$ & $57.6 \%(n=220)$ & \multirow[t]{3}{*}{$<0.001^{d}$} \\
\hline Some use ( $\leq 2$ calls weekly) & $15.3 \%(n=61)$ & $22.0 \%(n=84)$ & \\
\hline More use (>2 calls weekly) & $15.0 \%(n=60)$ & $20.4 \%(n=78)$ & \\
\hline \multicolumn{4}{|l|}{ CP voice calls } \\
\hline No use & $17 \%(n=67)$ & $20 \%(n=76)$ & \multirow[t]{3}{*}{$0.04^{d}$} \\
\hline Some use ( $\leq 2$ calls weekly) & $47.5 \%(n=186)$ & $46 \%(n=177)$ & \\
\hline More use (>2 calls weekly) & $35.5 \%(n=139)$ & $34 \%(n=129)$ & \\
\hline
\end{tabular}

${ }^{\mathrm{a}}$ Data included MP \& CP users only, ${ }^{\mathrm{b}}$ Wilcoxon signed-rank test, ${ }^{\mathrm{c}}$ Data included both non-users and users, ${ }^{\mathrm{d}}$ Fleiss-Everitt Chi square test based on non-missing data, The bold numbers represent statistically significant assoctions 
Table 3 Descriptive statistics for mobile phone voice call use and CogHealth ${ }^{\text {TM }}$ tasks [median $\left(25^{\text {th }}, 75^{\text {th }} \text { percentiles) }\right]^{\mathrm{a}}$

\begin{tabular}{|c|c|c|c|c|c|}
\hline \multirow[t]{2}{*}{ Tests } & \multirow[t]{2}{*}{ Parameters } & \multicolumn{2}{|l|}{ Baseline } & \multicolumn{2}{|l|}{ Follow-up } \\
\hline & & $\begin{array}{l}\text { MP voice calls } \\
\text { (n) }\end{array}$ & $\begin{array}{l}\text { Median } \\
\left(25^{\text {th }}, 75^{\text {th }} \text { percentiles }\right)\end{array}$ & $\begin{array}{l}\text { MP voice calls } \\
\text { (n) }\end{array}$ & $\begin{array}{l}\text { Median } \\
\left(25^{\text {th }}, 75^{\text {th }} \text { percentiles }\right)\end{array}$ \\
\hline \multirow{6}{*}{$\begin{array}{l}\text { Simple reaction time } \\
\text { (Detection task) }\end{array}$} & \multirow[t]{3}{*}{ Response time (ms) } & None (276) & $344(302,413)$ & None (243) & $317(288,359)$ \\
\hline & & Some (59) & $350(297,410)$ & Some (57) & $315(284,342)$ \\
\hline & & More (57) & $380(321,417)$ & More (83) & $316(282,362)$ \\
\hline & \multirow[t]{3}{*}{ Accuracy (\%) } & None (278) & $97(92,100)$ & None (243) & $97(95,100)$ \\
\hline & & Some (61) & $97(92,100)$ & Some (57) & $97(95,100)$ \\
\hline & & More (58) & $96(83,96)$ & More (83) & $97(93,100)$ \\
\hline \multirow{6}{*}{$\begin{array}{l}\text { Choice reaction time } \\
\text { (Identification task) }\end{array}$} & \multirow[t]{3}{*}{ Response time (ms) } & None (277) & $588(524,686)$ & None (243) & $549(481,619)$ \\
\hline & & Some (61) & $579(518,655)$ & Some (57) & $525(484,577)$ \\
\hline & & More (58) & $607(550,699)$ & More (83) & $558(493,601)$ \\
\hline & \multirow[t]{3}{*}{ Accuracy (\%) } & None (278) & $94(86,97)$ & None (243) & $94(88,97)$ \\
\hline & & Some (61) & $94(88,97)$ & Some (57) & $94(88,97)$ \\
\hline & & More (58) & $94(86,97)$ & More (83) & $94(89,97)$ \\
\hline \multirow{6}{*}{$\begin{array}{l}\text { One-back task } \\
\text { (Working memory) }\end{array}$} & \multirow[t]{3}{*}{ Response time (ms) } & None (278) & $965(792,1113)$ & None (243) & $863(707,1035)$ \\
\hline & & Some (61) & $1023(793,1164)$ & Some (57) & $860(741,971)$ \\
\hline & & More (57) & $976(826,1158)$ & More (83) & $930(748,998)$ \\
\hline & \multirow[t]{3}{*}{ Accuracy (\%) } & None (278) & $88(77,94)$ & None (243) & $94(86,97)$ \\
\hline & & Some (61) & $94(81,97)$ & Some (57) & $92(86,97)$ \\
\hline & & More (58) & $86(69,94)$ & More (83) & $94(82,97)$ \\
\hline \multirow{6}{*}{$\begin{array}{l}\text { One card learning task } \\
\text { (Visual recognition memory } \\
\text { \& attention) }\end{array}$} & \multirow[t]{3}{*}{ Response time (ms) } & None (278) & $1072(885,1322)$ & None (243) & $1047(854,1273)$ \\
\hline & & Some (61) & $1130(881,1387)$ & Some (57) & $1004(875,1170)$ \\
\hline & & More (58) & $1143(887,1293)$ & More (83) & $1052(936,1225)$ \\
\hline & \multirow[t]{3}{*}{ Accuracy (\%) } & None (278) & $59(49,66)$ & None (243) & $64(54,71)$ \\
\hline & & Some (61) & $57(50,64)$ & Some (57) & $63(53,68)$ \\
\hline & & More (58) & $58(49,64)$ & More (83) & $64(56,70)$ \\
\hline \multirow{6}{*}{$\begin{array}{l}\text { Go/NoGo } \\
\text { (Response inhibition task) }\end{array}$} & \multirow[t]{3}{*}{ Response time (ms) } & None (276) & $628(539,710)$ & None (243) & $592(505,676)$ \\
\hline & & Some (60) & $600(557,707)$ & Some (57) & $549(484,628)$ \\
\hline & & More (58) & $669(599,740)$ & More (83) & $574(516,655)$ \\
\hline & \multirow[t]{3}{*}{ Accuracy (\%) } & None (277) & $98(94,100)$ & None (243) & $98(96,100)$ \\
\hline & & Some (61) & $98(94,98)$ & Some (57) & $98(94,98)$ \\
\hline & & More (58) & $96(91,98)$ & More (83) & $98(96,100)$ \\
\hline \multirow{3}{*}{$\begin{array}{l}\text { Groton maze learning task } \\
\text { (Spatial \& executive ability) }\end{array}$} & \multirow{3}{*}{$\begin{array}{l}\text { Total number } \\
\text { of errors }\end{array}$} & None (278) & $69(54,86)$ & None (243) & $55(46,67)$ \\
\hline & & Some (61) & $65(56,76)$ & Some (57) & $56(49,69)$ \\
\hline & & More (58) & $72(55,89)$ & More (83) & $59(49,72)$ \\
\hline
\end{tabular}

${ }^{\mathrm{a}}$ Statistics of children who took part in baseline and follow-up $(n=412)$

The change in $\mathrm{CP}$ usage had no significant effect on most of the changes in cognitive outcomes. However, the 'increase' in number of CP calls weekly group had smaller mean increase in accuracy in the detection task compared to those in the 'no change or decrease' group.

We did not find gender to be an effect modifier (results not shown).

\section{Discussion}

This community-based longitudinal cohort study investigated whether the change in MPs/CPs in primary school children was associated with changes in cognitive function. The study contributes to the knowledge of psychological health and well-being associated with RF-EMF exposures in children, which has been part of the WHO 
Table 4 Descriptive statistics for cordless phone voice call use and CogHealth ${ }^{\mathrm{TM}}$ tasks $\left[\right.$ median $\left(25^{\text {th }}, 75^{\text {th }} \text { percentiles) }\right]^{\mathrm{a}}$

\begin{tabular}{|c|c|c|c|c|c|}
\hline \multirow[t]{2}{*}{ Tests } & \multirow[t]{2}{*}{ Parameters } & \multicolumn{2}{|l|}{ Baseline } & \multicolumn{2}{|l|}{ Follow-up } \\
\hline & & $\begin{array}{l}\mathrm{CP} \text { voice calls } \\
\text { (n) }\end{array}$ & $\begin{array}{l}\text { Median } \\
\left(25^{\text {th }}, 75^{\text {th }} \text { percentiles }\right)\end{array}$ & $\begin{array}{l}\mathrm{CP} \text { voice calls } \\
\text { (n) }\end{array}$ & $\begin{array}{l}\text { Median } \\
\left(25^{\text {th }}, 75^{\text {th }} \text { percentiles }\right)\end{array}$ \\
\hline \multirow{6}{*}{$\begin{array}{l}\text { Simple reaction time } \\
\text { (Detection task) }\end{array}$} & \multirow[t]{3}{*}{ Response time (ms) } & None (66) & $336(306,394)$ & None (76) & $326(294,373)$ \\
\hline & & Some (183) & $347(299,404)$ & Some (177) & $325(288,357)$ \\
\hline & & More (135) & $350(307,414)$ & More (123) & $309(279,352)$ \\
\hline & \multirow[t]{3}{*}{ Accuracy (\%) } & None (67) & $95(89,100)$ & None (76) & $97(95,100)$ \\
\hline & & Some (185) & $97(94,100)$ & Some (177) & $97(95,100)$ \\
\hline & & More (137) & $95(87,100$ & More (123) & $97(93,100$ \\
\hline \multirow{6}{*}{$\begin{array}{l}\text { Choice reaction time } \\
\text { (Identification task) }\end{array}$} & \multirow[t]{3}{*}{ Response time (ms) } & None (67) & $573(526,662)$ & None (76) & $545(496,595)$ \\
\hline & & Some (185) & $589(521,665)$ & Some (177) & $559(489,611)$ \\
\hline & & More (137) & $596(536,685)$ & More (123) & $529(476,592)$ \\
\hline & \multirow[t]{3}{*}{ Accuracy (\%) } & None (67) & $91(85,97)$ & None (76) & $94(91,97)$ \\
\hline & & Some (185) & $94(86,97)$ & Some (177) & $94(88,97)$ \\
\hline & & More (137) & $94(86,97)$ & More (123) & $94(88,97)$ \\
\hline \multirow{6}{*}{$\begin{array}{l}\text { One-back task } \\
\text { (Working memory) }\end{array}$} & \multirow[t]{3}{*}{ Response time (ms) } & None (67) & $958(751,1062)$ & None (76) & $883(729,985)$ \\
\hline & & Some (185) & $939(793,1114)$ & Some (177) & $865(715,1022)$ \\
\hline & & More (137) & $992(818,1132)$ & More (123) & $865(712,1020)$ \\
\hline & \multirow[t]{3}{*}{ Accuracy (\%) } & None (67) & $89(74,94)$ & None (76) & $93(86,97)$ \\
\hline & & Some (185) & $89(77,94)$ & Some (177) & $94(86,97)$ \\
\hline & & More (137) & $89(74,94)$ & More (123) & $91(84,97)$ \\
\hline \multirow{6}{*}{$\begin{array}{l}\text { One card learning task } \\
\text { (Visual recognition } \\
\text { memory \& attention) }\end{array}$} & \multirow[t]{3}{*}{ Response time (ms) } & None (67) & $1015(827,1274)$ & None (76) & $1065(940,1345)$ \\
\hline & & Some (185) & $1071(887,1312)$ & Some (177) & $1042(875,1218)$ \\
\hline & & More (137) & $1150(874,1340)$ & More (123) & $1013(862,1224)$ \\
\hline & \multirow[t]{3}{*}{ Accuracy (\%) } & None (67) & $56(49,65)$ & None (76) & $64(56,70)$ \\
\hline & & Some (185) & $60(51,66)$ & Some (177) & $65(56,72)$ \\
\hline & & More (137) & $59(50,65)$ & More (123) & $61(53,69)$ \\
\hline \multirow{6}{*}{$\begin{array}{l}\text { Go/NoGo } \\
\text { (Response inhibition task) }\end{array}$} & \multirow[t]{3}{*}{ Response time (ms) } & None (66) & $616(558,694)$ & None (76) & $569(517,656)$ \\
\hline & & Some (185) & $633(541,720)$ & Some (177) & $580(503,662)$ \\
\hline & & More (136) & $631(565,706)$ & More (123) & $583(503,689)$ \\
\hline & \multirow[t]{3}{*}{ Accuracy (\%) } & None (67) & $98(94,98)$ & None (76) & $98(96,100)$ \\
\hline & & Some (185) & $98(94,100)$ & Some (177) & $98(96,100)$ \\
\hline & & More (136) & $96(94,100)$ & More (123) & $98(94,100)$ \\
\hline \multirow{3}{*}{$\begin{array}{l}\text { Groton maze learning task } \\
\text { (Spatial \& executive ability) }\end{array}$} & \multirow{3}{*}{$\begin{array}{l}\text { Total number } \\
\text { of errors }\end{array}$} & None (67) & $65(55,84)$ & None (76) & $56(46,67)$ \\
\hline & & Some (185) & $69(54,80)$ & Some (177) & $56(46,68)$ \\
\hline & & More (137) & $68(55,84)$ & More (123) & $58(48,70)$ \\
\hline
\end{tabular}

${ }^{\mathrm{a}}$ Statistics of children who took part in baseline and follow-up $(n=412)$

high priority research agenda [8]. We found that number of calls and SMS weekly on MPs increased, whereas CP calls weekly remained unchanged from baseline to follow-up. Our results provide only limited evidence that change in the use of MPs/CPs in primary school children was associated with change in cognitive function.

The usage/ownership of MPs found in this sample of Australian children was low, but comparable to rates reported elsewhere. In the US, the use of MPs in children (aged 8 years and under) increased from 38 to $72 \%$ during 2011-2013 [21], In Europe, 33-83\% of children aged up to 14 years $[2,4,22]$, and $48 \%$ of Dutch children aged 5-6 years either used or owned a MP [14].

A relatively larger proportion of children used a $\mathrm{CP}$, compared to a MP, which is similar to that found in the Netherlands [14]. The number MP and CP calls reported in our study is also comparable to that observed elsewhere $[3,14]$. We found that a lower percentage of primary 
Table 5 Descriptive statistics [median $\left(25^{\text {th }}, 75^{\text {th }}\right.$ percentiles)] for the Stroop Color-Word test time ratios vs phone use type [CP (cordless phone) or MP (mobile phone) $]^{\text {a }}$

\begin{tabular}{|c|c|c|c|c|c|}
\hline \multirow[t]{2}{*}{ Forms } & \multirow[t]{2}{*}{ Parameters } & Exposure type & Baseline & Exposure type & Follow-up \\
\hline & & Groups (n) & Median $\left(25^{\text {th }}, 75^{\text {th }}\right.$ percentiles $)$ & Groups (n) & Median $\left(25^{\text {th }}, 75^{\text {th }}\right.$ percentiles $)$ \\
\hline \multirow{8}{*}{$\begin{array}{l}\text { Stroop ratio } \\
((\mathrm{B}-\mathrm{A}) / \mathrm{A})\end{array}$} & \multirow[t]{8}{*}{ Time ratio } & MP voice calls & & MP voice calls & \\
\hline & & None (276) & $0.09(0.02,0.16)$ & None (218) & $0.11(0.03,0.22)$ \\
\hline & & Some (60) & $0.10(0.02,0.18)$ & Some (84) & $0.13(0.06,0.22)$ \\
\hline & & More (60) & $0.08(0.003,0.15)$ & More (78) & $0.10(0.05,0.20)$ \\
\hline & & CP voice calls & & CP voice calls & \\
\hline & & None (66) & $0.07(0.01,0.14)$ & None (76) & $0.11(0.04,0.20)$ \\
\hline & & Some (184) & $0.89(0.007,0.17)$ & Some (177) & $0.12(0.04,0.24)$ \\
\hline & & More (138) & $0.11(0.04,0.17)$ & More (127) & $0.10(0.04,0.20)$ \\
\hline \multirow{8}{*}{$\begin{array}{l}\text { Stroop ratio } \\
((D-C) / C)\end{array}$} & \multirow[t]{8}{*}{ Time ratio } & MP voice calls & & MP voice calls & \\
\hline & & None (276) & $0.69(0.53,0.91)$ & None (218) & $0.66(0.52,0.84)$ \\
\hline & & Some (60) & $0.65(0.52,0.81)$ & Some (84) & $0.60(0.45,0.81)$ \\
\hline & & More (60) & $0.68(0.59,0.87)$ & More (78) & $0.66(0.50,0.83)$ \\
\hline & & CP voice calls & & CP voice calls & \\
\hline & & None (66) & $0.60(0.52,0.77)$ & None (76) & $0.56(0.46,0.71)$ \\
\hline & & Some (184) & $0.70(0.53,0.93)$ & Some (177) & $0.67(0.53,0.86)$ \\
\hline & & More (138) & $0.68(0.57,0.89)$ & More (127) & $0.66(0.52,0.85)$ \\
\hline
\end{tabular}

${ }^{a}$ Statistics of children who took part in baseline and follow-up $(n=412)$

Table 6 Regression results comparing the change in cognitive outcome (follow-up minus baseline) between those who increased their MP (or CP) calls weekly from baseline to follow-up, and those who did not increase or reduce their MP (or CP) usage

\begin{tabular}{|c|c|c|c|c|c|}
\hline \multirow[b]{3}{*}{ Tests } & \multicolumn{5}{|c|}{$\begin{array}{l}\text { Difference in cognitive outcome means between those who increased MP (or CP) use and those did } \\
\text { not increase or reduc their use }\end{array}$} \\
\hline & \multicolumn{3}{|l|}{ Voice calls on MP } & \multicolumn{2}{|c|}{ Voice calls on $\mathrm{CP}$} \\
\hline & Parameters & Estimate & $95 \% \mathrm{Cl}$ & Estimate & $95 \% \mathrm{Cl}$ \\
\hline \multirow[t]{2}{*}{ Detection task } & Response time $(\mathrm{ms})^{\mathrm{a}}$ & -0.008 & $-0.042,0.027$ & 0.007 & $-0.019,0.033$ \\
\hline & Accuracy $(\%)^{b}$ & 0.024 & $-0.036,0.084$ & -0.069 & $-0.127,-0.012$ \\
\hline \multirow[t]{2}{*}{ Identification task } & Response time $(\mathrm{ms})^{a}$ & -0.008 & $-0.034,0.018$ & 0.007 & $-0.011,0.024$ \\
\hline & Accuracy $(\%)^{b}$ & 0.012 & $-0.044,0.067$ & -0.047 & $-0.097,0.002$ \\
\hline \multirow{2}{*}{$\begin{array}{l}\text { One-back memory task } \\
\text { (Working memory) }\end{array}$} & Response time $(\mathrm{ms})^{\mathrm{a}}$ & 0.009 & $-0.018,0.036$ & 0.017 & $-0.006,0.041$ \\
\hline & Accuracy $(\%)^{b}$ & 0.014 & $-0.048,0.076$ & -0.029 & $-0.077,0.019$ \\
\hline \multirow{2}{*}{$\begin{array}{l}\text { One card learning task } \\
\text { (Visual recognition } \\
\text { memory \& attention) }\end{array}$} & Response time $(\mathrm{ms})^{\mathrm{a}}$ & 0.005 & $-0.033,0.043$ & -0.0008 & $-0.034,0.032$ \\
\hline & Accuracy $(\%)^{b}$ & -0.022 & $-0.054,0.009$ & -0.011 & $-0.049,0.026$ \\
\hline \multirow{2}{*}{$\begin{array}{l}\text { Go/NoGo } \\
\text { (Response inhibition task) }\end{array}$} & Response time $(\mathrm{ms})^{\mathrm{a}}$ & -0.030 & $-0.054,-0.006$ & 0.009 & $-0.013,0.032$ \\
\hline & Accuracy $(\%)^{b}$ & 0.011 & $-0.037,0.059$ & -0.013 & $-0.060,0.034$ \\
\hline Groton maze learning task & Accuracy (total no. of errors) & 6.22 & $2.13,10.31$ & -2.77 & $-8.77,3.24$ \\
\hline Time ratio $((B-A) / A)$ & Response time (s) & 0.056 & $0.021,0.090$ & -0.028 & $-0.069,0.013$ \\
\hline Time ratio $((D-C) / C)$ & Response time (s) & -0.048 & $-0.127,0.033$ & -0.003 & $-0.066,0.059$ \\
\hline
\end{tabular}

Reference group: no change or decrease in total average number of MP or CP calls weekly (exposure dichotomized: "no change or decrease" and "increase" in total average number of MP and CP voice calls weekly)

Adjusted for age at baseline, sex, ethnicity, SES (classified into quintiles), lag time between baseline and follow-up, handedness, and total screen time weekly (gaming and computer/Internet use)

The bold numbers represent significant assoctions

${ }^{\mathrm{a}} \log _{10}$ transformed data, ${ }^{\mathrm{b}}$ Arcsine transformed hit rate 
school children own/use a MP compared to ownership/ usage rates reported in secondary school children $[1,11]$.

The follow-up analysis also showed that more children reported using/owning a MP than was reported by parents. A similar pattern was seen in our cross-sectional data [10]. This could be due to how the questions related to MP ownership and/or uses were asked and/or how they were understood by the parents and children. The potential implications of this for epidemiological studies have been discussed in the literature [1, 10, 23]. We suggest that the findings associated with the use of $\mathrm{CP}$ could be more accurate since the $\mathrm{CP}$ was used only at home and parents may thus have directly observed their child's CP exposures.

The children had better cognitive performance at follow-up compared to baseline, which is expected as a natural part of development and has been reported in the literature [24]. In the cross-sectional analysis [10], the 'more' MP users had slower responses for the Go/ NoGo task. However, the longitudinal analysis found that the 'increase' in MP calls group decreased their response time from baseline to follow-up more than the 'no change' group for this task. Furthermore, the crosssectional findings observed that the 'more' $\mathrm{CP}$ (but not $\mathrm{MP}$ ) users took longer when trying to overcome distraction (Stroop). In the longitudinal analysis no difference was seen in the CP groups, however the 'increase' in MP calls group had a larger mean increase in response time for a Stroop interference task ((B-A)/A) than the 'no change' group. Accuracy in executing the Groton maze learning task was increased in both MP groups from baseline to follow-up but less so in the 'increase' in MP calls group. Accuracy in the detection task increased for both $\mathrm{CP}$ groups from baseline to follow-up but less so for the 'increase' in CP calls group. The 'increase' in the $\mathrm{CP}$ calls group had lower accuracy in the detection task compared to those in the 'no change or decrease' group.

Our previous longitudinal study involving Australian secondary school children showed an increase in MP voice calls was associated with slower simple response time, but quicker working memory [1]. We did not find any similar results in the current study. A Swiss cohort study found that brain RF-EMF exposure among a 'high' exposed group (aged 12-17 years) was associated with a decrease in figural memory [11]. The memory tasks (i.e., one-back and one card learning) used in our study and the figural memory task were different. Therefore, caution is advised when comparing the findings. In the Netherlands, children aged 5-6 years showed that high $\mathrm{CP}$ users demonstrated slower response times in an inhibitory control and cognitive flexibility compared to nonusers [14]. Although not identical, to the extent that the inhibitory control test and Go/NoGo task in our paper reflect the 'inhibitory control' cognitive process, and if $\mathrm{CP} /$
MP affects it, we would expect to see a similar pattern of results across the two studies. However, this was not the case: the Netherlands study reported slower reaction time in 'high' CP users, while we observed a faster reaction time amongst the group that increased their MP use.

Our study is the first to evaluate a longitudinal association of MP/CP use and change in cognition in a representative community-based sample of young children. We prospectively collected data at two time points. The study cohort consisted of a relatively large sample size, compared to those employed in provocation studies [25-27]. We assessed eight cognitive tasks, compared to the Swiss study (which only assessed two tasks) and the $\mathrm{ABCD}$ study (which assessed four tasks). This allowed us to look for potential effects on different cognitive domains as well as for whether consistent patterns of effects were present across multiple tasks (vs just in one task) within a cognitive domain.

The main limitation of the study was that phone exposure measures were self-reported. Our study was therefore likely to misclassify exposure and could provide biased findings. Objective exposure measurements using MPbased apps should be considered for prospective epidemiological studies, whenever possible [28]. Furthermore, the one-year follow-up time in our study may not be long enough to detect potential changes in cognitive outcomes associated with MPs/CPs exposure. A further follow-up may be more sensitive at determining whether a long-term usage of MPs and CPs affects cognition [29].

Another limitation of the study was that we did not assess motivation of the children while evaluating cognitive tasks. There may have been effects that were missed due to this. Furthermore, the high performance on the cognitive tasks may have reduced discriminatory power of the tasks and increased type II error, along with the misclassification of children's use of MP/CP reported by parents/guardians.

\section{Conclusions}

Our study shows that a larger proportion of children used CPs compared to MPs. The increase in MP usage was significantly associated with larger reduction in response time for response inhibition task, smaller reduction in the number of total errors in the Groton maze learning task, and larger increase in response time for a Stroop interference task. The increase in CP usage had no significant effect on the most of the changes in cognitive outcomes. Due to the small numbers of mobile and cordless phone calls, the observed changes in cognitive tasks could be pure chance findings. The use of mobile phones, as reported by children and parents was different. This should be taken into account in future studies by performing objective measurements of mobile phone exposures, whenever possible. 


\section{Abbreviations}

ABCD: Amsterdam born children and their development; CP: Cordless phone; EXPOSURE: Examination of psychological outcomes in students using radiofrequency devices; MP: Mobile phone; RF-EMF: Radiofrequencyelectromagnetic field; SES: Socio-economic status; WHO: World Health Organization

\section{Acknowledgements}

The authors would like to thank: David Derby for providing advice on the test battery, and Kristen Benke, Sherli Li, Alyse Lennox, Harbeer Ahedi, Richard Cyngler, Elisa Wood, Natasha Kinsman, Maria Sicari, Nuwan Leitan, Allison Byrnes, Sheila Cyril, Teo Jin Ye, Penelope Oliver, Pinar Yilmaz, Amy Finlay, Nicholas Benikos, and Lisa-Marie Greenwood for conducting interviews and testing the participants.

\section{Funding}

The study was funded by the National Health and Medical Research Council, Australia (grant number APP 545927).

\section{Availability of data and materials}

Please contact author for data requests. The data sharing should follow Monash University data sharing protocol, if any.

\section{Authors' contributions}

CRB: performed and interpreted the statistical analyses, wrote the initial manuscript, and approved the final manuscript. GB: Was involved with design and data collection, interpreted the statistical analyses, critical review of manuscript and final approval of submitted manuscript. CLS: performed and interpreted the statistical analyses, critically reviewed the manuscript, and approved the final manuscript. MR: interpreted the statistical analyses, critically reviewed the manuscript, and approved the final manuscript. CD: coordinated and supervised data collection at all sites, critically reviewed the manuscript, and approved the final manuscript. AD: coordinated data collection at one site, was involved with interpretation of results, and approved the final manuscript. SM: Involved in initial setup of the project, questionnaire development, ethics approval, and data collection at schools, and approved the final manuscript. MRS: conceptualized and designed the study, reviewed and revised the manuscript, and approved the final manuscript. RJC: Was involved with design, data collection and interpretation of results, critically reviewed the manuscript, and approved the final manuscript. RW: Provided guidance on the choice and interpretation of the statistical analyses, critically reviewed the manuscript, and approved the final manuscript. JK: Involved with the data collection strategy, interpretation of results, critically reviewed the manuscript, and approved the final manuscript. MJA: conceptualized and designed the study, critically reviewed and revised the manuscript, and approved the final manuscript.

\section{Competing interests}

MJA and CD hold small parcels of shares in Telstra which operates a cell telephone network in Australia. MR received salary from the National Health and Medical Research Council grant during the first part of the work on this paper. The other authors declare no conflict of interest.

\section{Consent for publication}

The consent to publish the polled findings from individual participants' data was received from guardians/parents of children.

\section{Ethics approval and consent to participate}

The study received approvals from the Victorian Department of Education and Early Childhood Development, New South Wales Department of Education and Communities, Catholic Education Offices of Victoria and New South Wales, Monash University Human Research Ethics Committee and the University of Wollongong Human Research Ethics Committee.

Written or verbal informed consent to participate was obtained from the parent or guardian of each student, teachers of the participating classes, and principals of the participating schools.

\section{Publisher's Note}

Springer Nature remains neutral with regard to jurisdictional claims in published maps and institutional affiliations.

\section{Author details}

${ }^{1}$ Centre for Population Health Research on Electromagnetic Energy (PRESEE), School of Public Health and Preventive Medicine, Monash University, 553 St Kilda Road, VIC 3004 Melbourne, Australia. ${ }^{2}$ Australian Centre for Electromagnetic Bioeffects Research, School of Psychology, University of Wollongong, Wollongong, NSW 2522, Australia. ${ }^{3}$ School of Health Sciences, Swinburne University of Technology, Hawthorn, VIC 3122, Australia.

Received: 22 February 2017 Accepted: 14 April 2017

Published online: 19 June 2017

\section{References}

1. Thomas S, Benke G, Dimitriadis C, Inyang I, Sim M, Wolfe R, Croft RJ, Abramson MJ. Use of mobile phones and changes in cognitive function in adolescents. Occup Environ Med. 2010;67(12):861-6.

2. Mezei G, Benyi M, Muller A. Mobile phone ownership and use among school children in three Hungarian cities. Bioelectromagnetics. 2007;28(4): 309-15.

3. Redmayne M. New Zealand adolescents' cellphone and cordless phone user-habits: are they at increased risk of brain tumours already? A crosssectional study. Environ Health. 2013;12:5.

4. Böhler $\mathrm{E}$, Schüz J. Cellular telephone use among primary school children in Germany. Eur J Epidemiol. 2004;19(11):1043-50.

5. Söderqvist F, Hardell L, Carlberg M, Mild KH. Ownership and use of wireless telephones: a population-based study of Swedish children aged 7-14 years. BMC Public Health. 2007;7(1):105.

6. Kabali HK, Irigoyen MM, Nunez-Davis R, Budacki JG, Mohanty SH, Leister KP, Bonner Jr RL. Exposure and use of mobile media devices by young children. Pediatrics. 2015;136(6):1044-50.

7. Kheifets L, Repacholi M, Saunders R, Van Deventer E. The sensitivity of children to electromagnetic fields. Pediatrics. 2005;116(2):e303-13.

8. van Deventer $E$, van Rongen $E$, Saunders R. WHO research agenda for radiofrequency fields. Bioelectromagnetics. 2011;32(5):417-21.

9. Bailin A, Milanaik R, Adesman A. Health implications of new age technologies for adolescents: a review of the research. Curr Opin Pediatr. 2014;26(5):605-19.

10. Redmayne M, Smith CL, Benke G, Croft RJ, Dalecki A, Dimitriadis C, Kaufman J, Macleod S, Sim MR, Wolfe R, Abramson MJ. Use of mobile and cordless phones and cognition in Australian primary school children: a prospective cohort study. Environ Health. 2016;15(1):26.

11. Schoeni A, Roser K, Röösli M. Memory performance, wireless communication and exposure to radiofrequency electromagnetic fields: a prospective cohort study in adolescents. Environ Int. 2015;85:343-51.

12. Abramson MJ, Benke GP, Dimitriadis C, Inyang IO, Sim MR, Wolfe RS, Croft $\mathrm{RJ}$. Mobile telephone use is associated with changes in cognitive function in young adolescents. Bioelectromagnetics. 2009;30(8):678-86.

13. Sudan M, Olsen J, Arah OA, Obel C, Kheifets L. Prospective cohort analysis of cellphone use and emotional and behavioural difficulties in children. J Epidemiol Community Health 2016:jech-2016-207419.

14. Guxens M, Vermeulen R, van Eijsden M, Beekhuizen J, Vrijkotte TG, van Strien RT, Kromhout $H$, Huss A. Outdoor and indoor sources of residential radiofrequency electromagnetic fields, personal cell phone and cordless phone use, and cognitive function in 5-6 years old children. Environ Res. 2016:150:364-74.

15. Cardis E, Richardson L, Deltour I, Armstrong B, Feychting M, Johansen C, Kilkenny M, McKinney P, Modan B, Sadetzki S. The INTERPHONE study: design, epidemiological methods, and description of the study population. Eur J Epidemiol. 2007;22(9):647-64.

16. Stroop JR. Studies of interference in serial verbal reactions. J Exp Psychology. 1935;18(6):643

17. Van der Elst W, Van Boxtel MP, Van Breukelen GJ, Jolles J. The Stroop ColorWord Test influence of age, sex, and education; and normative data for a large sample across the adult age range. Assessment. 2006;13(1):62-79.

18. Thomée S, Härenstam A, Hagberg M. Mobile phone use and stress, sleep disturbances, and symptoms of depression among young adults-a prospective cohort study. BMC Public Health. 2011;11(1):66.

19. Samkange-Zeeb F, Berg G, Blettner M. Validation of self-reported cellular phone use. J Expo Sci Environ Epidemiol. 2004;14(3):245-8.

20. Inyang I, Benke G, Morrissey J, McKenzie R, Abramson M. How well do adolescents recall use of mobile telephones? Results of a validation study. BMC Med Res Methodol. 2009;9:36. 
21. A Common Sense Media Research Study. Zero to Eight Children's Media Use in America 2013. https:/www.commonsensemedia.org/research. Accessed 18 Dec 2016.

22. Davie R, Panting C, Charlton T. Mobile phone ownership and usage among pre-adolescents. Telematics Inform. 2004;21(4):359-73.

23. Khorseva NI, Grigor'ev lu G, Gorbunova NV. Psychophysiological indicators for children using mobile phones. Communication 2. Results of four-year monitoring. Radiats Biol Radioecol. 2011;51(5):617-23.

24. Mollica CM, Maruff P, Collie A, Vance A. Repeated assessment of cognition in children and the measurement of performance change. Child Neuropsychol. 2005;11(3):303-10.

25. Regel SJ, Achermann P. Cognitive performance measures in bioelectromagnetic research-critical evaluation and recommendations. Environ Health. 2011;10(1):10.

26. Valentini E, Ferrara M, Presaghi F, De Gennaro L, Curcio G. Systematic review and meta-analysis of psychomotor effects of mobile phone electromagnetic fields. Occup Environ Med. 2010;67(10):708-16.

27. Verrender A, Loughran S, Dalecki A, McKenzie R, Croft R. Pulse modulated radiofrequency exposure influences cognitive performance. Int J Radiat Biol. 2016;92(10):603-10.

28. Bhatt CR, Redmayne M, Abramson MJ, Benke G. Instruments to assess and measure personal and environmental radiofrequency-electromagnetic field exposures. Australas Phys Eng Sci Med. 2015;39:29-42.

29. Ng TP, Lim ML, Niti M, Collinson S. Long-term digital mobile phone use and cognitive decline in the elderly. Bioelectromagnetics. 2012;33(2):176-85.

\section{Submit your next manuscript to BioMed Central and we will help you at every step:}

- We accept pre-submission inquiries

- Our selector tool helps you to find the most relevant journal

- We provide round the clock customer support

- Convenient online submission

- Thorough peer review

- Inclusion in PubMed and all major indexing services

- Maximum visibility for your research

Submit your manuscript at www.biomedcentral.com/submit

) Biomed Central 